\title{
A case study on Mummified Foetus in a heifer
}

Azizunnesa, B.C. Sutradhar, B.C. Das, M. F. Hossain ${ }^{1}$ and M.O. Faruk ${ }^{1}$

Dept. of Medicine and Surgery, Faculty of Veterinary Medicine, Chittagong Veterinary and Animal

Sciences University Chittagong, Bangladesh. msazizunnesa@yahoo.com; 'Department of Livestock and

Fisheries, Chittagong, Bangladesh

A farm economy depends upon a calf per year per cow. Mummified foetus is a reproductive disorder which is responsible for farm economic loss by extending the inter calving period as well as foetal loss. The incidence of mummified foetus in cattle is low and sporadic but the incidence may be higher in some herds (Roberts, 1971). In cattle fetal mummification occurs with an incidence of $0.13-1.8 \%$ (Barth, 1986). In Bangladesh there is no accurate account about the incidence of mummified foetus in cow but sporadically mummified foetus occurred throughout the country. Talbot \& Hafs (1974) treated the mummified foetus in cow with Prostaglandin $F_{2 \alpha}$. However, such foetus might be treated with intramuscular administration of Stilbestrol, Estradiol, Respositol diethylstilbestrol or manual removal of the persistent corpus luteum (Roberts, 1971). Most mummified foetuses will remain in the uterus until treatment is given to expel them or until their removed by caesarean section (Wenkoff \& Manns, 1977). The choice of treatment of this problem is injection of prostaglandin $F_{2 \alpha}$ and in failure case caesarean section. There is some evidence of failure to expel mummified foetus by the treatment with prostaglandin $F_{2 \alpha}$. To overcome this type of complication the author has had personal interest to deliver the mummified foetus with cesarean section rather than Prostaglandin $F_{2 \alpha}$ injection. Arthur et al. (1996) showed that treatment of mummified foetus with Prostaglandin $F_{2 \alpha}$ create some complexicity in cattle like maceration of mummified foetus and packed in the birth canal instead of expelled out. It occurs as a consequence of uterine infection, pyometra, chronic endometritis and finally the animal should therefore be sent for slaughter.

\section{Case description}

A three and half year's old and $300 \mathrm{~kg}$ body weight Sahiwal crossbred heifer was suffering from estended gestation. After three month of artificial insemination (AI) the pregnancy was diagnosed per rectally by a artificial inseminator. Near about 7 months of gestation the udder and abdomen had increased in size but the heifer did not deliver the foetus even after 290 days of gestation. Foetal mummification occurs after the $1^{\text {st }}$ trimester of gestation (Roberts, 1986). Apparently the pregnant heifer was normal because all the clinical findings including heart rate, pulse rate, temperature, appetite, posture and gait were normal. On rectal palpation there was no foetal movement, closed cervix and a hard mass in the uterus without the palpation of cotyledone, fremitus and foetal fluid that revealed foetal mummification. Roberts (1986) stated that if the mummified foetus exists longer period in the uterus, the condition become drier, firmer, and more leather like tissues of the foetus. He also stated that the cotyledone and fremitus are not palpated.

\section{Operative Procedure}

The caesarean operation was done by standing position at the farm. The animal was controlled by providing both the physical as well as chemical methods. Paravertibral regional anaesthesia as described by Weaver (1986) \& Kumar (1996) and light sedation was performed as mentioned by Kumar (1996). Lignocaine hydrochloride 2\% (Jasocaine ${ }^{\circledR}$, Jason, BD Ltd) and Diazepam $\left(\right.$ Sedil $\left.^{\circledR}\right)$ was used for paravertebral regional anaesthesia and light sedation respectively. Bamboo and rope were used to support the animal during the operation.

Ventral to the left paralumbar fossa was selected for operation and this area was prepared for operation by clipping, shaving and finally sterilizing with Tr. iodine soaked cotton. During operation $1000 \mathrm{ml}$ of $5 \%$ Dextrose saline was infused intravenously to compensate dehydration from fluid and blood loss. Following aseptic preparation of the operative field, a 14 inches long vertical incision along the lower flank was made to open the abdomen, as described by Noordey (1994). The distended gravid uterus was pulled out through the incised opening (Plate 1). Drapes and sterile gauge were used to prevent the leakage of uterine fluid to the peritoneal cavity. A longitudinal incision along the greater curvature of uterine horn was made to remove the mummified 
foetus (Plate 2). There was absent of foetal fluid and the whole foetal surface was sticky chocolate colour. Placental portion was dried and attached to the foetal body, was a haematic mummification. Arthur et al. (1996) supported that haematic mummification is more common and in this condition foetal fluid are resolved but the foetus and membranes are surrounded by a viscious, chocolate coloured material. The inner surface or endometrium, and peritoneal cavity were thoroughly flushed out with normal saline and 200 $\mathrm{ml}$ Metro iv $^{\circledR}$ (Opsonin, Bangladesh) to compensate the visceral moisture and to combate anaerobic infections (Rahman et al., 1994). The incised uterus, peritoneum and muscle were sutured with cat gut No. 2 subsequently and finally the skin was closed with Nylon thread. A Benzoin seal was applied over the sutured line. The animal was then monitored daily for any complication up to complete healing.

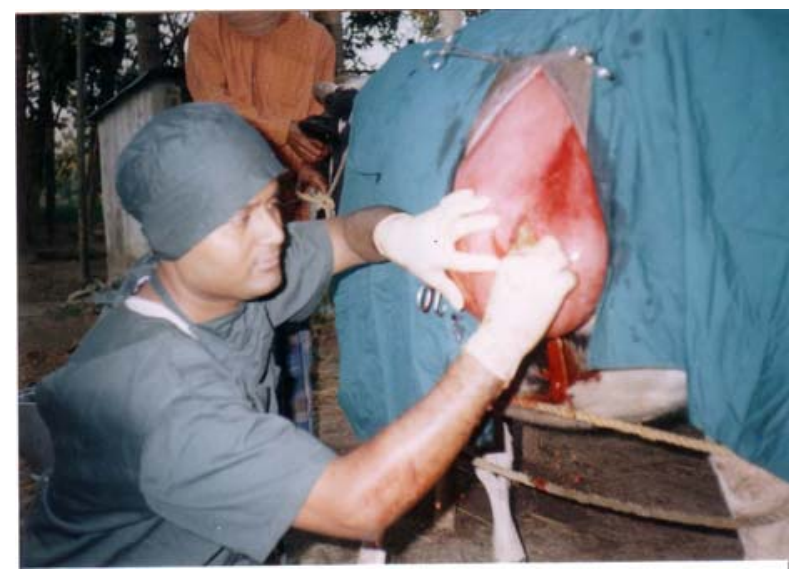

Plate 1. Incision on uterus to remove mummified fetus

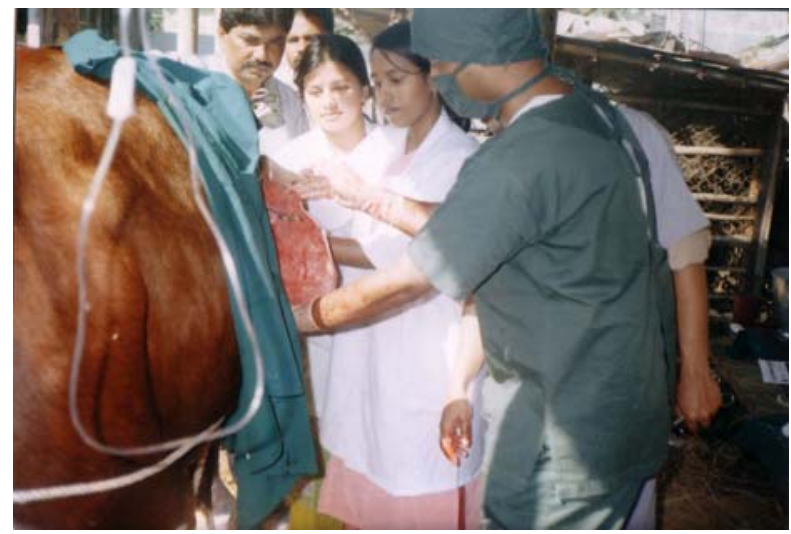

Plate 2. Opening the uterus which contain mummified fetus

\section{Post operative care and advice}

Just after operation synthetic preparation of Oxytocin (Piton $\mathrm{S}^{\circledR}$, Organon, BD. Ltd) $3 \mathrm{ml}$ was given intramuscularly to prevent uterine bleeding if any. The main concern was deputed to prevent the possible toxemia, to alleviate the inflammatory pain and to check the secondary infection or complications. Dextrose saline $5 \%$ (1 liter/day) was continued intravenously for 3 days after operation to reduce the risk toxemia, to balance stress, and energy expenses. SP-Vet ${ }^{\circledR}$ (Acme Laboratories BD. Ltd) 2.5 grms was injected intramuscularly for each day and continued up to 5 days of operation to prevent bacterial infection. $10 \mathrm{ml}$ of Astavet $^{\circledR}$ (Acme Laboratories BD. Ltd) was injected intramuscularly daily up to 5 days of operation. On the day $10^{\text {th }}$ the suture of the skin was removed and it was noticed that the wound had healed completely.

Temperature, respiration, heart rate and other related physical examinations were done and recorded regularly. Periodic rectal palpation was done to assess the condition of the uterus during post operative care. The recorded range of temperature was $101.3-101.6^{\circ} \mathrm{F}$ up to 7 days of operation, the respiration rate was $18-20$ /minute and pulse rate was 70-80/minute. The appetite and general appearance of the cow were satisfactory with apparent signs of recovery for the first few days. The animal was kept in clean and dry place and was supplied adequate balance feed. After one month of operation the animal showed oestrus but the animal was inseminated on next subsequent heat just after 21 days of first heat. Pregnancy was confirmed by rectal palpation on 35 days it gave birth normally after completion of full gestation period. Similar result was found by Roberts (1986). He noted that cows usually conceive on the $1^{\text {st }}$ or $2^{\text {nd }}$ oestrous cycle after expulsion of mummified foetus. This result is also supported by Moore \& Richardson (1995) who observed the prognosis for fertility after expulsion of mummified foetus was good. 


\section{References}

Arthur, G.H. Noakes, D.E. Person, H. \& Parkinson, T.J. 1996. Sequelae to embryonic or foetal death. In: Veterinary Reproduction and Obstetrics. $7^{\text {th }}$ edn. Philadelphia; W.B. Saunders. pp.127-128.

Barth, A.D. 1986. Induced abortion in cattle. In: Current therapy in Theriogenology. $2^{\text {nd }}$ edn. D.A. Morrow, Philadelphia; W. B. Saunders. pp. 205.

Kumar, A. 1996. Local anesthesia. In: Veterinary Surgical Technique. $1^{\text {st }}$ edn. Vikas publishing house, Pvt Ltd. Jangpura, New Delhi. pp. 117-119.

Moore, A.A. \& Richardson, G.F. 1995. Uterine torsion and fetal mummification in a cow. Canadian vet. J. 36(11): 705-706.

Noordey, J.L. 1994. Caesarean section in the cow. Food animal surgery. $3^{\text {rd }}$ edn. VLS. pp. 155-167.
Rahman, M.M. Rahman, M.A. Alam, M.G.S. \& Hossain, M.A. 1994. Operative management of dystocia due to non opening cervix in a cow. Bang. Vet. J. 28: 79-82.

Roberts, S.J. 1971. Veterinary Obstetrics and Genital Diseases. $2^{\text {nd }}$ edn, pp. 170-174.

Roberts, S.J. 1986. Veterinary Obstetrics and Genital Diseases, Theriogenology. $3^{\text {rd }}$ edn. pp. 213-233.

Talbot, A.C. \& Hafs H.D. 1974. Termination of a bovine pregnancy complicated by mummified fetus. Vet. Record. 95: 512.

Weaver, A.D. 1986. Para vertebral block. In Bovine Surgery and Lameness. $1^{\text {st }}$ edn. Bullen and Tanners Ltd. pp. 20.

Wenkoff, M.S. \& Manns, J.G. 1977. Prostaglandin induced expulsion of bovine fetal mummies. Canadian Vet. J. 18(2): 44-45.

Manuscript received on 20.08.2009 accepted on 28.10.2009 